\title{
PENGARUH KETERPUTUSAN POLA ASUH ORANGTUA TERHADAP PENDIDIKAN ANAK
}

\author{
Aufia Aisa', M. Mujabun ${ }^{2}$ \\ Universitas KH. A. Wahab Hasbullah Jombang \\ Email; aufiaaisa2@gmail.com, m.mujabun@gmail.com
}

\begin{abstract}
Intellectual development in the life of a teenager must be balanced with good values, morals and morals. Children who do not have a harmonious relationship with their parents in childhood are unlikely to be able to develop super egos that are strong enough, so they can be people who often violate social norms. Independence and moral maturity always put forward in every behavior in every life. The ability that exists in a child's life makes them able to have good morals and attitudes in the future. A person's basic personality is formed in childhood. The processes of development that occur in a child coupled with what is experienced and accepted during the time of his children gradually enable him to grow and develop into an adult human. It is hoped that parents can get to know the growth and development of their sons and daughters as early as possible to find the possibility of abnormalities or deviations in development. The existence of cooperation and a joint approach by experts from various sciences and activities will greatly help the development of children. And the most important point is the parents who are most responsible in developing the overall existence of children, including here physical and psychological needs, so that children can grow and develop towards a harmonious and mature personality.
\end{abstract}

Keywords; divorce, parents, children.

\section{PENDAHULUAN}

Pada akhir abad ke-17, seorang filsuf Inggris yang terkenal (John Locke, 1632-1704) mengemukakan bahwa pengalaman dan pendidikan bagi anak merupakan faktor yang paling menentukan dalam perkembangan anak ibaratnya adalah "secarik kertas yang masih kosong" bagaimana nanti bentuk dan corak kertas tersebut bergantung pada cara kertas tersebut ditulisi. John Locke juga mengemukakan akan pentingnya pengaruh pengalaman dan lingkungan hidup terhadap perkembangan anak. Anak adalah pribadi yang masih bersih dan peka terhadap rangsangan yang berasal dari lingkungan. Karena itu, orangtua sangat berperan penting dalam mengisi secarik kertas kosong tersebut mulai dari bayi.

Tidak selalu terjadi korelasi positif antara pengetahuan dan tindakan. Di antara proses kewajiban yang bersifat musikal adalah proses pertumbuhan dan perkembangan pengetahuan, serta membentuk sikap dan tingkah laku. Seorang individu yang melakukan perbuatan tercela pada waktu tertentu ternyata tidak selalu karena ia tidak mengetahui bahwa perbuatan itu tercela, atau tidak sesuai dengan nilai dan norma sosial. 
Ada bentuk tingkah laku yang mudah dilihat secara jelas dan diukur dan ada pula sebaliknya, semisal tindakan secara fisik, itu mudah dilihat dan diukur. Akan tetapi, di dalamnya tercakup juga sikap mental yang tidak selalu mudah ditanggapi, kecuali diduga dapat menggambarkan sikap mental tersebut.

Patokan yang berlaku dalam kehidupan masyarakat adalah nilai, misalnya adat kebiasaan dan sopan santun, serta nilai-nilai yang terkandung dalam Pancasila yang merupakan nilai-nilai hidup dan menjadi pegangan seluruh warga negara Indonesia. Jadi, nilai adalah ukuran benar-salah, baik-buruk, boleh-tidak boleh, indah-tidak indah suatu prilaku atau pernyataan yang berlaku dalam kehidupan suatu kelompok masyarakat (Husdarta \& Saputra Y.M, 1999).

Oleh karena itu, perilaku seorang dalam kehidupan di masyarakat akan didasari sikap dan nilai, sedangkan ajaran tentang baik-buruk suatu perbuatan, kelakuan, akhlak, kewajiban, dan sebagainya adalah moral (Toenggoel P. Siagian, 1985). Moral mengatur segala perbuatan yang dinilai baik dan perlu dilakukan, serta sesuatu perbuatan yang dinilai tidak baik dan perlu dihindari. Kemampuan seseorang untuk membedakan antara perbuatan yang benar dan yang salah, semua itu berkaitan dengan moral.

Dengan demikian, yang mendasari dan mengendalikan seseorang dalam bersikap dan bertingkah laku di antaranya adalah moral. Sebagai pendidik, misalnya kesadaran akan adanya hubungan antar semua bagian perkembangan dan bermanfaat untuk perencanaan kurikulum untuk berbagai kelompok usia anak.

Kebutuhan untuk mendukung perkembangan yang sehat pada semua bagian diri anak hampir dipastikan digerakan oleh kurikulum untuk bayi, anak-anak yang baru belajar berjalan dan anak usia prasekolah. Berbeda dengan kurikulum untuk sekolah anak dasar yang diarahkan sebagai usaha-usaha untuk membantu anak-anak mengembangkan pemahaman-pemahaman konseptual yang dapat diaplikasikan pada mata pelajaran yang dipelajari (Soerjono Soekamto, 1989).

Orangtua perlu menjaga agar keluarga tetap harmonis. Keharmonisan dalam hal ini tidaklah selalu identik dengan adanya orangtua utuh (ayah dan ibu), sebab dalam banyak kasus orangtua single terbukti berfungsi efektif guna membantu perkembangan psikososial anak. Suasana demokratis merupakan hal paling penting yang perlu diperhatikan oleh orangtua agar tercipta dalam keluarga, sehingga komunikasi yang baik dapat menjalin antar remaja dengan orangtua maupun saudara-saudaranya. Segala konflik yang timbul akan mudah diatasi dengan adanya komunikasi timbal balik antara anak dan orangtua. 
Maka sebaliknya, hubungan sosial antara satu sama lain menjadi rusak jika komunikasi yang terjalin terasa rigid, dingin, terbatas, menekan, dan penuh otoritas. Hal itu juga menyebabkan konflik yang berkepanjangan sehingga suasana menjadi tegang, panas dan emosional.

Hurlock (1978) menyatakan bahwa remaja akan mempunyai kemampuan menyesuaikan diri dan sosialisasi yang baik dengan lingkungan sekitarnya jika ia berasal dari keluarga yang penuh perhatian, hangat dan harmonis. Dia juga mengemukakan bahwa ayah harus dapat mengerti keadaan anak-anaknya, bertindak sebagai teman atau rekan bagi anakanaknya, membimbing perkembangan anak serta melakukan sesuatu untuk dan bersama-sama dengan anak-anaknya.

Peranan ayah bisa tampak melalui aktivitas-aktivitas ayah yang berusaha mengembangkan kemampuan intelektualnya. Makna "ayah" bagi seorang anak adalah sosok yang lebih sering keluar rumah dibandingkan dengan ibunya, lebih banyak dan lebih keras dalam menghukum. Tetapi di lain pihak, anak menyadari bahwa ayah lebih banyak mengetahui, memiliki sesuatu dan merupakan kepala keluarga.

Melalui sikap dan tingkah laku ayah sebagai kepala keluarga, anak akan belajar bertingkahlaku layaknya seorang laki-laki. Tahan menghadapi masalah, tabah, tidak suka menangis, tegas dan berani. Orangtua yang baik harus memiliki kualitas sebagai ayah dan ibu dan menjadi pelindung anak-anaknya. Orangtua harus dapat memerankan tugasnya dengan baik.

Orangtua harus cukup memberikan afeksi, menghargai dan menghormati anak sebagai subjek dan senantiasa bersedia melakukan apapun demi anaknya. Dalam batas-batas tertentu, orangtua akan bermurah hati dan mau mengabulkan permintaan anaknya. Mereka adalah tokoh yang adil dalam menanamkan disiplin. Orangtua merupakan sumber cinta dan sumber kasih sayang yang dapat menaruh perhatian bila anak dalam kesulitan dan nestapa. Hal ini hanya dapat terlaksana dengan baik melalui kesatuan yang serasi antara ayah dan ibu serta keadaan rumah yang harmonis.

Melalui hubungan yang penuh perlindungan dan suasana intim dengan orangtuanya, anak akan memperoleh kepuasan, membangun "basic trust", perasaan aman serta mengembangkan egonya. Dengan pribadi yang sehat ini, anak dapat memiliki perasaan percaya diri maupun percaya terhadap dunia luar (Hurlock E.B, 1999).

Dari uraian-uraian di atas, kita dapat melihat betapa penting dan kompleksnya peranan ayah dalam suatu keluarga. Dia merupakan gambaran dari kekuatan, keamanan dan 
kebijaksanaan bagi ibu serta anak-anaknya. Tetapi seringkali dijumpai macam alasan, mungkin karena ayah harus pergi ke tempat lain untuk menunaikan tugasnya, meninggal atau hidup berpisah karena perceraian.

Ketentraman rumah tangga akan terganggu, dan hal inipun akan membawa akibat bagi perkembangan anak. Pertama, seberapa jauh keterikatan anak dengan ayah. Bila sebelumnya anak memiliki hubungan yang dekat dengan ayah, dan ayah banyak melibatkan diri dalam mengembangkan anaknya, maka suatu saat ketidakhadiran ayah benar-benar merupakan suatu kejadian traumatis bagi seorang anak. Kedua, jenis kelamin anak juga mempunyai pengaruh tertentu. Bagi anak laki-laki, ayah merupakan tokoh identifikasi. Melalui ayah, anak laki-laki dapat belajar bersikap, bertingkah laku, berperasaan sebagaimana layaknya seorang laki-laki. Setiap anak laki-laki membutuhkan sosok ayah sebagai contoh, sehingga kehilangan ayah berarti kehilangan sumber identifikasi. Bagi seorang wanita, ketidakhadiran ayah tidak begitu mempengaruhi perkembangannya. Ketiga, kapan saatnya perpisahan itu terjadi juga merupakan sesuatu yang penting. Ketidakhadiran ayah tidak begitu dirasakan oleh anak-anak yang masih kecil, karena anak-anak ini lebih terikat dan tergantung pada ibunya. Mereka lebih banyak menghabiskan waktu bersama ibu daripada ayah. Tetapi tidak demikian halnya dengan anakanak prasekolah atau sekolah. Kehadiran dan peranan ayah mulai dirasakan. Kehidupan anak pada masa itu masih terpusatkan dalam keluarganya, sehingga ketidakhadiran ayah akan mengakibatkan anak merasa tidak aman. Keempat, pengaruh ketidakhadiran ayah dalam sikap ibu kepada anaknya. Bila ibu cukup kuat dan mampu mengatasi goncangan-goncangan tersebut dengan mudah, maka akibatnya bagi anak tidak begitu buruk. Terakhir, yang penting dari hal ini adalah sebab ketidakhadiran sang ayah. Ketidakhadiran ayah dengan alasan bekerja di luar kota akan mempunyai efek berbeda bila dibangdingkan dengan anak yang ditinggal karena kematian atau sebuah perceraian.

Sebab-sebab dari ketidakhadiran sosok ayah akan menentukan bagaimana pengaruhnya terhadap anak. Kepergian ayah karena tugas kerja, sering kali menimbulkan situasi tertekan bagi anaknya ataupun orangtuanya. Sangat berat bagi siapapun juga dan setiap anggota keluarga untuk menyesuaikan diri sebab perpisahan. Proses penyesuaian diri seorang anak akan kembali jika ayah telah pulang dari tugasnya. Selama kepergian ayah, anak menjadi sangat tergantung dengan orang dewasa yang lain. Dia juga memiliki kecemasan dan ketakutan yang lebih banyak bila dibandingkan dengan anak-anak lain yang tumbuh dalam rumah, dimana kedua orangtuanya masih lengkap (Singgih D. Gunarsa, Yulia Singgih D. Gunarsa, 2011, hlm. 
155). Tallent menambahkan, biasanya anak akan menyesuaikan diri dengan baik, memiliki latar belakang keluarga yang harmonis, serta menghargai pendapat anak (Tallent, 2007).

Hal ini disebabkan karena anak akan memberikan persepsi bahwa rumah adalah suatu tempat tinggal yang membahagiakan dan berasal dari keluarga harmonis karena masalah yang dihadapi anak semakin sedikit. Begitu juga sebaliknya, anak akan terbebani dengan masalahmasalah yang sedang dihadapi orangtuanya tersebut, sehingga timbul persepsi keluarganya sedang berantakan atau kurang harmonis. Kecenderungan menjadi remaja nakal akan terlihat pada remaja yang dibesarkan dalam keluarga yang kurang harmonis

\section{METODE}

Terdapat dua metode yang dipakai dalam penulisan artikel ini, yakni metode longitudinal dan metode observasi. Longitudinal adalah metode psikologi perkembangan anak yang mempelajari kelompok kerja individual selama periode diperpanjang. Data akan dikumpulkan di bagian luar penelitian secara berulang-ulang melalui arus penelitian.

Pada kasus ini, studi longitudinal dapat berlangsung selama beberapa dekade atau berakhir terbuka. Keunggulan metode psikologi perkembangan anak ini adalah memungkinkan para peneliti untuk melihat perubahan-perubahan yang terjadi seiring waktu.

Metode observasi merupakan suatu cara untuk mengamati semua tingkah laku yang dapat dilihat pada waktu tertentu atau pada tahap perkembangan tertentu dengan menggunakan observasi alami. Catatan data berupa tingkah laku anak yang terjadi secara alami dalam seharihari. Proses pencatatan tanpa merubah situasi atau melakukan kontrol terhadap situasi yang direncanakan. Contohnya, observasi yang dilakukan pada kehidupan anak yang menyangkut kepribadian dan hubungannya dengan kedua orangtua.

\section{HASIL DAN PEMBAHASAN}

Sebelum membahas lebih lanjut terkait hal-hal yang substansial dari judul yang diangkat, peneliti akan memperjelas terlebih dahulu. Pertama, hakikat seorang anak dalam pertumbuhan dan perkembangannya sangat membutuhkan kedua orangtuanya. Orangtua adalah sosok yang paling bertanggungjawab terhadap memperkembangkan eksistensi anak, termasuk di sini kebutuhankebutuhan fisik dan psikis, sehingga anak dapat tumbuh dan berkembang ke arah kepribadian yang matang dan harmonis.

Sayang sekali, hubungan antara kedua orangtua tersebut tidaklah senantiasa sempurna. Setiap keluarga tentu tidak luput dari persoalan. Mula-mula dimulai persoalan kecil tetapi 
akhirnya menjadi persoalan besar. Oleh karena itu, sering kali keseimbangan akan mengganggu dan membahayakan kehidupan keluarga. Tidak jarang perselisihan dan pertengkaran di antara kedua orangtua tersebut berakhir dengan perceraian.

Perceraian sering diakhiri dengan kepergian ayah untuk hidup berpisah dengan anak dan istrinya. Ketidakhadiran ayah dan kunjungannya yang tidak teratur setelah perceraian akan memengaruhi anak dan ibu. Istri yang ditinggalkan oleh suaminya harus berperan sebagai ibu sekaligus ayah bagi anak-anaknya. Tanggung jawab ibu bertambah, dia harus mencari nafkah dan mengambil keputusan yang seharusnya menjadi tugas ayah.

Ketidakhadiran ayah ini bisa membawa pengaruh langsung ataupun tidak bagi anakanak. Pada saat anak masih dalam masa bayi, ketidakhadiran ayah hanya membawa akibat yang tidak langsung bagi anak. Karena pada masa ini anak lebih tergantung dan terikat pada ibunya. Hal ini berbeda pada masa sekolah, peranan ayah mulai disadari dan dirasakan oleh anak, sehingga kepergian ayah berakibat langsung bagi anak tersebut (Singgih D. Gunarsa, Yulia Singgih D. Gunarsa, 2011:151).

Adanya pengaruh dari lingkungan hidup terhadap sesuatu tingkah laku, juga menimbulkan pertentangan (Singgih D. Gunarsa, 2016). Perilaku-perilaku sosial anak-anak korban perceraian orangtua nampak jelas mengganggu suasana kelas dan jalannya proses belajar mengajar. Perilaku-perilaku mereka memang meresahkan para guru selama proses belajar mengajar.

Proses belajar mengajar seringkali mengalami sedikit kendala. Kendala yang sering dihadapi oleh para guru adalah tingkah laku, perbuatan dan tindakan anak-anak secara perilaku sosial yang mengganggu suasana kelas dan proses belajar mengajar. Ruang Bimbingan dan Konseling (BK) pada setiap lembaga pendidikan seharusnya dimaksimalkan untuk membimbing anak-anak dan berusaha untuk menyadarkan mereka dengan memberi nasehat-nasehat disertai penggunaan metode persuasif.

Staff Bimbingan dan Konseling biasanya memberikan bimbingan sampai tiga kali. Apabila siswa yang bersangkutan sikapnya tidak berubah, maka guru bimbingan dan konseling akan memanggil orang tua untuk menelusuri latar belakang masalah yang dihadapi anak tersebut baik dari sisi keluarga, lingkungan maupun kondisi psikis sang anak.

Pemanggilan orangtua yang bersangkutan tidak lain untuk membangun sebuah komunikasi antara orangtua dan sekolah dan mengajak kerjasama dengan mereka dalam rangka membina anaknya. Namun kenyataannya, terkadang pihak sekolah sering sekali menemui kendala yang sangat berarti ketika mencoba melakukan bimbingan dan konseling terhadap anak 
misalnya ketika pihak sekolah memanggil para orangtua murid, orangtua murid sering tidak mau datang dengan berbagai alasan.

Usaha-usaha pihak sekolah untuk menyelamatkan anak didik sudah kelihatan memang demikian baik, artinya kewajiban penyelenggara pendidikan selalu ditempuh dengan baik sesuai dengan tahapan-tahapannya. Kendala seperti inilah yang membuat anak bermasalah sulit untuk menemukan solusi karena tidak terbangun sebuah kerjasama antara pihak sekolah dengan orangtua murid.

Oleh karena itu, menangani peserta didik yang berperilaku agresif akibat pengaruh perceraian orangtua memerlukan kerjasama yang baik antara orangtua dan lembaga pendidikan dengan memberikan layanan individu, konseling wali peserta didik, dan bila perlu guru pembimbing melakukan kunjungan rumah (home visite).

Layanan individu peserta didik demikian dapat menyadarkan bahwa perilaku agresif peserta didik dapat menjerumuskannya ke dalam tindakan-tindakan negatif yang tidak bermanfaat. Perilaku ini dapat merusak masa depan sang anak. Selain itu, komunikasi dan koordinasi dengan orangtua juga dapat memperbaiki hubungan dalam keluarga.

Orangtua peserta didik merasa malu ketika mendapat panggilan dari sekolah karena tindakan negatif sang anak. Secara tidak langsung, orangtua akan melakukan komunikasi yang lebih intensif dengan anaknya agar tidak dipanggil kembali ke sekolah sehingga secara tidak langsung keharmonisan keluarga peserta didik perlahan dapat diperbaiki.

Untuk menangani kasus demikian, jika orangtua peserta didik sudah mau datang memenuhi panggilan guru BK atau guru pembimbing, maka tidak perlu melakukan home visite. Pada dasarnya home visite dilakukan jika orang tua tidak memenuhi panggilan pihak-pihak sekolah. Semua perihal di atas adalah contoh negatif dampak dari perceraian kedua orangtua yang berujung pada kegagalan pendidikan anak.

Individu yang memiliki pengalaman menyenangkan yang tinggi akan lebih mudah memperoleh kebahagiaan dalam hidupnya. Inilah yang disebut dengan individu bahagia. Hal ini sesuai dengan pernyataan responden ketika diberikan pertanyaan mengenai pengalaman yang paling menyenangkan, mereka menjawab bahwa pada usia tigabelas tahun sudah dapat bekerja secara mandiri. Walaupun orang melihatnya dengan kesedihan, namun bagi remaja tersebut secara pribadi merasa bahagia, apalagi ketika mendapatkan banyak support dari anggota keluarga. Sebaliknya, bagi individu yang memiliki pengalaman rendah dan tidak menyenangkan, serta memiliki kemampuan untuk meningkatkan kebahagiaan di masa depan. 
Hal ini ditunjukkan pada hasil wawancara pada saat pertanyaan mengenai rencana yang akan dilakukan di masa depan. Kebanyakan mereka memberikan jawaban untuk mencari kerja terlebih dahulu guna membiayai adik-adiknya yang masih kecil. Langkah ini guna menggantikan peran kepala keluarga dan bentuk bertanggung jawab untuk semua anggota keluarga.

Tindakan yang positif akan mudah dicapai oleh remaja yang memiliki masa kebahagiaan, karena kebahagiaan merupakan perasaan positif yang dirasakan remaja, sehingga mendorong seorang untuk melakukan berbagai hal positif. Individu yang bahagia adalah individu yang memiliki pengalaman menyenangkan yang tinggi dan memiliki kemampuan meningkatkan kebahagiaan di masa depan. Mendapatkan dukungan dari keluarga dan teman merupakan pengalaman yang menyenangkan bagi setiap remaja untuk menambah semangat remaja dalam menjalani kehidupan sehari-hari.

Selain itu, bertemu atau berkumpul dengan keluarga dan teman juga membuat remaja tersebut merasa lebih senang. Para remaja juga merasa bahagia ketika terlibat dalam kegiatan yang sangat disukai, seperti melakukan hobinya yaitu menyanyi atau-pun membahagiakan orangtua dan keluarganya (Aminah Andayani T. R, \& Karyanta N. A, 2012).

\section{KESIMPULAN}

Umumnya pendidikan adalah mempersiapkan peserta didik agar memiliki banyak pengetahuan, tetapi tidak tahu cara memecahkan masalah-masalah yang dihadapai dalam kehidupan bermasyarakat. Pendidikan lebih mempersiapkan peserta didik untuk menjadi anak yang pandai dan cerdas, tetapi kurang mempersiapkan peserta didik untuk menjadi anak yang baik. Masalah berkenaan dengan baik dan buruk menjadi kajian bidang moral.

Demikian juga dalam mengembangkan aspek moral, bagaimana cara membantu peserta didik untuk menjadi anak yang baik; mengetahui, berperilaku, bersikap baik dan benar. Sikap dan perilaku moral dapat dikembangkan melalui pendidikan dan penanaman nilai atau norma yang dilakukan secara terintegrasi dalam pelajaran maupun kegiatan yang dilakukan anak di keluarga dan sekolah. Pendidikan bukan hanya mempersiapkan anak menjadi manusia cerdas, tetapi juga menjadi manusia yang baik, berbudi luhur, dan berguna bagi orang lain.

Pengembangan moral melalui pendidikan mestinya bukan hanya mengajarkan nilai-nilai sebagai slogan. Hal ini tampak pada moral yang diyakini penganut dan moral budaya yang diterima masyarakat. Proses pendidikan dan pembelajaran moral diteladankan orang tua dan dilakukan secara terpadu (integrated) pada setiap peluang dan berbagai kegiatan sekolah. 
Pendidik adalah mengajarkan keteraturan hidup, disiplin serta melatih dan membiasakan peserta didik bermoral dalam perilaku dan kegiatannya.

Jadi dalam kehidupan anak, peran dari berbagai kalangan sangatlah penting, baik orangtua, lingkungan dan sekolah. Semoga kita bisa menjadi orangtua yang dapat menjaga keutuhan rumah tangga kita agar anak-anak kita bisa tumbuh menjadi sosok yang dapat membanggakan kedua orangtuanya dan mendapatkan kasih sayang tanpa kekurangan sesuatu apapun.

\section{ACKNOWLEDGEMENT}

Terimakasih peneliti haturkan, terutama kepada segenap civitas akademika Universitas KH. Wahab Hasbullah Jombang, karena dengan segala bantuannya, peneliti mampu merampungkan penelitian ini dengan baik sebagai bentuk tanggung jawab Tridarma Perguruan Tinggi. Kajian dan diskusi yang telah diberikan sangat memberi arti kepada peneliti guna mengembangkan komplesitas kepenulisan karya ilmiah selanjutnya. Penelitian ini merupakan penelitian kolaborasi yang peneliti tulis tanpa mendapat biaya dari luar.

\section{BIBLIOGRAFI}

Aminah, Andayani, T. R., \& Karyanta, N. A. (2012). Proses penerimaan anak (remaja akhir) terhadap perceraian orang tua dan konsekuensi psikososial yang menyertainya. Jurnal Ilmiah Psikologi Candrajiwa, 1(3).

Husdarta \& Saputra Y.M. (1999). "Perkembangan Peserta Didik". DEPDIKBUD Mc Graw-Hill.

Hurlock, E.B. (1999). Psikologi Perkembangan. Suatu Pendekatan Sepanjang Rentang Kehidupan. Erlangga.

John Locke. (2016). Dasar dan Teori Perkembangan Anak. BPK Gunung Mulia.

Singgih D. Gunarsa, Yulia S. D. Gunarsa . (2011). Psikologi Perkembangan Anak dan Remaja. BPK Gunung Mulia.

Singgih D. Gunarsa. (2016). Dasar dan Teori Perkembangan Anak. BPK Gunung Mulia.

Soerjono Soekamto. (1989). "Remaja dan Permasalahannya”. Rajawali.

Tallent. (2007). http://www.edumuslimin.org/index.php?option=article $\mathrm{rf}=30$ diakses pada tanggal 11 April 2019 pukul 15.45 WIB.

Toenggoel P. Siagian. (1985). "Pendekatan Pokok dalam Mempertimbangkan Remaja Masa Kini”. Prisma. 